\title{
Fallacious Friendship in Shobhaa De's Novel: Snapshots
}

\author{
Ms. Siddiqui Jabeen Rafiuddin \\ Ph.D Research Scholar in English, Dept. of Languages, JJT University, Jhunjhunu, Rajasthan, India.
}

\begin{abstract}
The present paper focuses on the fallacious friendship in Shobhaa De's novel Snapshots. De is a writer of Indian English Literature which has a long tradition of women novelist who portrayed India of their time. Feminist like Kamala Markandaya, Namita Gokhale, Manju Kapur, Anita Desai, Arundhati Roy, and Shashi Deshpande has given their genuine aspirations focussing on the parochial Society. De writes what she sees in the society. She exposes the secrets of neurotic and amoral people of urban Society. Swati, the main protagonist due to lack of parental love and influenced by western culture possess self-centred and capricious nature misleads her life and deceives her five school friends for material gain and takes revenge of them.

Keywords: Feminist, reverence, fragile, tapping, humiliation, desperate, immoralness, deceitfulness, choir, mislead,de cepted.
\end{abstract}

In the enlightened phase of Indian feminist, many Indian novelists portrayed their reflecting work by their meaningful work of Indian English novels. The women novelist attained a certain height and accomplished world-wide fame are Kamala Markandaya, Anita Desai, Ruth Prawer Jhabwala, Nayantara Sahgal, Manju Kapur, Namita Gokhale, Arundhati Roy, and Shobhaa De. They imitated and followed British Writers like Bronte Sisters, George Eliot, Jane Austen and Virginia Woolf in depicting their Characters .These novelist resisted effectually and numerically in concerning the inward reflections of women and get familiarize with their own identification. Their depiction in the novels constantly shares undisputed credibility to their feminist ideas, reverence and perspectives. This paper introduces the reader about the novel Snapshots (1995) in which the five school friends get cheated by Swati due to lack of confidence in them and they lack the ability to detect her deceitfulness.

Shobhaa De a writer of eighteen books, both fiction and non-fiction and an explosive novelist of contemporary urban India and a wide read columnist in foremost publications. She is also a grandiloquent advocate of the feminist cause and a budding genius in the domain of Modern English Literature.

She portrays the true picture of modern metropolitan life. Her novels deal with men and women of urban elite class their obsessions, disappointments and insecurities. She possesses naive realism and determines the characters and reflects them as they are and not they should have been. She writes to awake the society by informing the rotten truth prevailing in the urban elite class of metropolitan cities of India mostly Mumbai. She entangles to a great depth in the inner psyche of the characters and digs out the concealed conducts and immoralness of the characters adopted by them due to the influence of western culture. Friendship is one of the most admirable component of Indian culture is shattered and lost its value in Shobhaa De's Snapshots.

People have persuadibility, sensitiveness and the ability to apprehend, it relies on the person to use or misuse it in relations. In certain cases its use depends on the situations and occasionally on the intention of the person. In the novel Snapshots Swati's deep-rooted annoyance, fretful feelings and disenchantment resulted into fragile fallacious friendship.

Friendship emphasizes a very significant role in one's life; it furnishes laughter, share worries and memories and has fun. Exactly it happened in the novel Snapshots. The Six School friends of Santa Maria High School Swati, Aparna, Reema, Rashmi, Noor and Surekha gathered on the invitation of Swati Bridges at Reema's house to recollect past memories, with some old photographs and significantly the old gang friends came close to one another for the lunch on Tuesday at the time when they were leading inevitable, unremarkable, lives of domesticity and imagined ecstasy. They were having problems of their own but they all attended it. Their unconcealed hostility poisoned the atmosphere and their friendship turned to be nightmarish. The novel Snapshots portrays the post-colonial era which concretizes the adventures of powerful, liberated new woman.

Snapshots exhibit an urban society where men stand on the outer boundary and women contest for power. It is a message of Shobhaa De to exemplify the deceitful friendship prevailing in Urban India. It is a plot of revenge to Swati the protagonist because she lies and deceit her friends due to her flippant nature. She took life as a game and always thought to win and if the game is lost she plans to take revenge of the winner. This instinctive emotion arose in her due to restlessness and discontentment in life.

The novelist Shobhaa De has portrayed Swati the protagonist as an example to all Oriental women who avoids all ways and abject adopted by her to lead a nice and admirable life. In this novel Swati is a rival of her 
friends and she takes revenge of each of them. It is difficult to categorize her physically, her unusual looks captivates everybody. She had inherited her nutmeg complexion from her Malayali father and rather exotic features with tip-tilted Oriental eyes from her mother. She is jealous of Aparna and considers her a rival, for Reema a trophy guest, for Rashmi a supercilious bitch, for Noor a high-class whore, while for Surekha; she is an erratic, egoistic and manipulative.

Swati was inconstant, confident, sexy, flirtatious, financially and socially more powerful, also a singer and manipulative from her School days. She exercises control over others. She is socially tactful and competent and makes an honest expression. Her spontaneity tends to disharm suspicion, which makes easier for her to get away with her lies. She presents herself effectively in front of others. Noor was liked by Swati in the class. Noor was a harmless sort of girl and sweet. She was esthetical and impractical. Swati enslaves Noor and lowers her dignity which impels Noor to commit suicide. Noor's fault was that she revealed Swati's secret of tapping through electronic bugs placed secretly by her in the room. Swati developed an imperious attitude towards Noor after subjugating her brother Nawaz in illicit unprincipled sexual relationship with him just to win Nawaz from Noor. She exults under the idea that she is far superior to all women. She desires more and more nearly the complete entirety that attracted her. She had also stolen articles from Noor's house. Nawaz mentions:

"If Mummy finds out, that's it .She'll ban your friend from coming over. Next time I see Swati I'm going to ask her about the silver ashtray. And the ivory horse."1

She deceives Noor scolds her and tells that nobody needs her not even her own brother whom she has kept the incest relationship. She furiously uttered:

"I've got your sick little love-notes too, what fun. Imagine how they'll appear in print. You'll be exposed for what you are and always have been-suicidal psychotic bitch. You is nothing, Noor. Nothing at all...." 2

The fear of exposure of incest relationship with her brother led Noor to feel ashamed and jeopardise all over her life and she committed suicide by closing herself in the bathroom.

Swati also deceived Reema. Reema was a fringe person, vague and wooly. She is a sweet, soft-spoken person without any real opinions. Reema was attracted to Raju in School days and she had sex with him in the back seat of a stolen car but she didn't tell anybody. She was pregnant and was sent to home from School in disgrace. She failed in her terminals and was scared, guilty, confused and ashamed she avoided Raju. Swati a shrewd and domineering figure turns Reema's helplessness to her advantage with her help of her aunt. But the fact remains that by helping Reema in the hour of her desperate situation, Swati obliges her for a whole life time. As Reema was very dear to the teacher and her grades were also better than Swati and she had also bagged the lead role in the annual school play and also use to refuse Swati to give a lift to school each day. This caused enviousness about Reema to Swati and she discloses the Reema's secret. The other friends protected her but uttered:

"It would've gone off without a hitch, and Reema's misadventure would have remained a secret, but someone squealed. It was never known who the culprit was but everybody suspected Swati." ${ }^{3}$

No doubt Swati helped Reema at the moment but she acts as a disclosure and revealed the secret of Reema to her parents by informing through them an anonymous bad written letter in her own handwriting. Due to which Reema had to marry Ravi a man not of her choice and Raju her boyfriend was murdered.

The other character Aparna suffers and undergoes humiliation at the hands of Swati. Seeds of rivalry, jealousy and hatred were laid in Swati's mind much earlier during her school days when by common consent, Aparna was selected as the most photogenic and best looking girl. She justifies that women are women's worst enemy. Jealousy about Aparna hurts her self-esteem and finally ends her friendship with her. She provokes jealousy to achieve hold over her friends. Husband became a disgusting word for Aparna. Swati takes vengeance of each and every girl. She has hostility and covetousness of her friends owed to some shrewish reason of her own. She used to giggle happily with Rohit and would make Aparna to feel like an interloper in her own home. She lures Aparna's husband and destroys her harmonious life. At the get- together moment as to lure Aparna, Swati started to massage her telling that it's a Chinese method which she had learnt from a Hollywood therapist. Aparna stopped her telling her not to be so theatrical and asked her not to manipulate her .Aparna utters:

"There isn't one thing in the world you'd do for nothing. You didn't in the past and you certainly won't now. I have asked myself -----------..You were and are the most dangerous person I know." ${ }$

The above words despised Swati and she became more furious about Aparna and presented some envelopes written by Rohit to her. At this moment Swati wanted to expose Aparna's husband and her affair with him and how he loved her instead of his wife and appreciated her in bed performance. Aparna expresses openly with flood of tears flowing from her eyes:

"You are lying, she said, blowing her nose. 'I don't believe you. I knew Rohit better than he knew himself, yes, he did love me. Only me. Nothing you say alter that. You destroyed our marriage. You killed me. What did I ever do? You turned on me like a viper?", 
Due to which Aparna lures Prem her office employee from his wife Renu. It simply happens due to Aparna's winning the best girl trophy during her School days. Swati has not forgotten the humiliation, the hurt after losing the trophy caused to her. It left a scar on her mind which made her disappointed and devastated and she took revenge of Aparna by destroying the marital relationship of her and ruined her sleep.

Swati used Dolly's friendship in charge of choir practice and insincere behaviour to win the 'Best House' shield headed by Aparna. In that mater she'd also instructed Dolly to devastate the rival Green House efforts by spying on their practices, finding out about their chosen songs and discovering the plays they were planning.

She looked down Dolly, who serves her at her will, simply because she admits as having grounded twenty laxatives into Priya's soft drink, the talented young girl playing Eliza Doolittle in the Dramatics competition for the Green House production of Pygmalion. Dolly had torn two of her showy costumes and had done eavesdropping on Swati's directions, to stop her from winning the 'Best House' shield of the year. Someone had spotted Dolly fixing the drink and it finally squealed and Dolly was rusticated from the School. Not a single girl was willing to talk to her for weeks after the incident. Meanwhile she develops the most intimate and spiritual relationship with her married friend Surekha. Dolly reacted when she came to know that Swati had invited Surekha:

“Those female nearly destroyed me. I haven’t forgiven her. And never will. But you------why? Why do you want to go? What will you get out of this Stupid lunch? Have you asked yourself one question-----no' I'm sure not. The only reason Swati has asked you is to hurt me. What else?"6.

Dolly remains deprived and reckless throughout her life due to her physical and intellectual degradation by Swati. The fear of getting exposed jeopardise Dolly and she finally commits suicide, a social crime and catastrophically ends her life. It shows Swati's artificial and undesirable element of life which goes against the Indian culture and customs and human values.

The dilemma of modern Indian women is better comprehended by Bijay Kumar Das when he remarks that:

"Shobhaa De dives deep into the hearts of liberated, upper-class women in the contemporary society and depicted her characters as they are and not as they not as they should have been.",

De writes frankly about something, if it is unpleasant and follows Dr. Freud's philosophy and exposes the dark secrets of life which are invisible to one's eyes. She notifies the danger and the frightening situations going in urban elite society.

Swati is unscrupulous and excessively prone towards personal egotism. Her dishonest demeanour abhors Surekha for the simple reason that she helped Dolly in her ignominious situations, thereby hurting her ego boundlessly.

Swati is egotistical and does not help Rashmi 'the all rounder', an unwed mother because of her being physically superior to her. She tries to degrade her by hurling remarks at her:

"What are you afraid of? You have not reputation to safe guard. And your bastard Son must know he has a whore for a mother."

The utterance of malicious statement injures Rashmi's reputation in front of other friends and they started to wrestle each other in a despicable way. Blood started to ooze out from Rashmi's arms and legs and they broke an Onyx lamp in Reema's house.

Some might think that some specific form of brain dysfunction influence such false behaviours. The psychologist Charles Ford is correct as he mentions that:

"Lies are advantageously used by individuals and social groups to obtain power, sexual gratification, and material goods or wealth."

No doubt Swati was ready to face the future in an uncertain way and she get the sense of well being and confidence in her life for that purpose she played it tactfully and betrayed the most trusted relationship the friendship.

Swati wanted more and more everything that fascinated her. The only way to acquire them she thought is money and materials. Her inordinate desire propels her to make a blue film, for the western viewers which she does stealthily and the plan was failed. The acknowledgement of achievement overseas confirmed adulation back home. She planned to use her friends' voices in the reunion to produce a bold meaty serial 'Sisters of the Sub-Continent to get more and more money. The novelist is also against the idea that some Indians are selling their conscience, individuality, national feelings, the meaning and misuse of friendship for worldly gains from the west and inflicting irreparable damage to national honour and reputation. Swati exasperates jealousy to achieve success but jealousy about her friends has not helped her to achieve anything in life. This type of friendship leads us far away from humanity and life loses its sense of purpose .Therefore one can pronounce that:

"Discovering India through Indian eyes."10 
Swati's pursuit for success is relentless. She emerges as a winner from the fifth standard in exams, competitions and plays. She goes to London and joins the School of Drama but she becomes a case of high determination and was unsuccessful. She was the child, neglected by her parents. Her mother was a prominent social worker and Professor of Anthropology, and had committed her life to the upliftment of the toiling masses and was rarely at home. Her father also was a Civil Engineer who spent most of his time on sites out of town and their home was lone and cold. Swati lacks the parental love, care, tenderness and honour in her childhood and was accustomed to different ayahs to take care of her. To maintain the perfect embodiment in her home according to her mother, they could seldom retain servants. In the absence of affection and sympathy in her childhood she develops with a malicious and criminal mind and was unable to justify her own deeds. She felt alone without her parents. She absorbs the environment and the company of different ayahs. She interacted with the bad environment from a very early age and when grown-up adopted their addictions like booze and sex, abuses and mental conditions of the ayahs. She forges tangible emotional connection to her adult caretaker. Her nature becomes flippant which adulterated her life, mind and body and degraded her to complete zero. Her dark aspect of human nature makes her to take revenge of her friends. She herself put her in harm due to her illegal or dangerous behaviour. She didn't understand the relationships and the importance of relationships in her life due to which she betrayed her friends and was unsuccessful in her marital life and have increased risk of substance abuse. Swati might have felt that she have been hurt in some way by her parents or by life situations. She felt that the only way for her to gain significance is to avenge her on others resulting in fallacious friendship. Lack of parental love results a feeling of insecurity, low self warmth and potentially difficulty in maintaining interpersonal relationships to her. Esteemed Psychologist Donald Winnicott once stated that:

"Babies do not become distinct individuals immediately after birth. They wade into personhood gradually, buoyed by the calm and protective waters of family. Long after the umbilical cord is cut, a second far stronger cord remains. This second cord is the subject of attachment theory of epigenetic inheritance, of the nature/nurture debat.It is spun from love and kinship, these ethereal fibres, and extends backwards through the generations and outward through family, community, country, and ultimately, the entire planet."11

Parenting really matters! It leads her to cause physical, mental and emotional damage of her. To deal with this problem parents must give love, time and care in childhood to their children to develop good and loyal friendship and also other internal relationships. Mary Wollstonecraft an eighteen century writer, philosopher defines the problems of women and the status of women in her book A Vindication of the Rights of women as it is noted in:

"I allow that more friendship is to be found in the male than the female world, and that men have a higher sense of justice." ${ }^{12}$

These don't seem like the words of the feminist she was. She wanted to explain that men are fair in friendship and give justice to friends than women. Shobhaa De on the other hand has undoubtedly and unambiguously rebel against this traditional approach. She understands the psyche of women and is keen to project the rein of power firmly in her female characters hand without considering the pros and cons of the situation to create their own world.

In the article the negative friendship created havoc and thus it was destructive, dubious, unhealthy and badly ended. Swati's inner mind is irrefutably visible through her fallacious friendship in which she had victimized her friends for her contentment but fails. It suggests that children need parental love and guidance to develop them and to attain the fullest development of their personality to become a complete human being. Parents must give them time and teach their wards the lesson of preserving ethnicity, loyalty, affection and unceasing respect with one another to lead them from going astray. This piece of literature will definitely shape the minds within the society and it compels the readers to think over this critical problem going in Indian urban elite society. All five friends were socially anxious they get cheated by Swati due to lack of ability to detect her deceitfulness. To get love and social recognition Swati swings from hither and thither and misleads her life and decepted her friends.

References:

[1] De, Shobhaa.1995.Snapshots.NewDelhi: Penguin Books, p.84

[2] Ibid., p.302

[3] Ibid., p.139

[4] Ibid., p.253

[5] Ibid., p.256

[6] Ibid., p.220

[7] Das, Bijay Kumar.1997."The Author and the Text: A Study of Shobhaa De's Snapshots", Prof.R.S.Pathak, Indian Fiction of the Nineties. New Delhi: Creative Books, p.16.

[8] De, Shobhaa.1995.Snapshots.NewDelhi: Penguin Books, p.304

[9] Ford, Charles.V.1999.Lies! Lies! Lies! The psychology of Deceit. Washington: American psychiatric Press, Inc.p.21

[10] Vellani, Sarita.1991.”Interview with David Davidar,"Seminar, 384, August, p.41

[11] Dr.Nicole, Letourneau\& Justin, Joschko.2013.Scientific Parenting.Toronto:DunDurn.p.201.

[12] Dr.Block,Joel D\&Diana Greenberg.2002.Women\&Friendship.USA: Wellness Institute, Inc.p.28 